\title{
Histopathological study of the Achilles tendon after exposure to bisphenol-A and its subsequent treatment with platelet growth factors
}

\author{
Cristina Bellido" ${ }^{1 \#}$, Carlos Abellán ${ }^{1 \#}$, Ana Molina ${ }^{1}$, Alfonso Blanco ${ }^{2}$, \\ and Rosario Moyano ${ }^{1 *}$ \\ ${ }^{1}$ Department of Pharmacology, Toxicology and Legal and Forensic Medicine, Veterinary Faculty, \\ University of Córdoba, Campus de Rabanales Carretera Madrid-Cádiz s/n, Córdoba, Spain \\ ${ }^{2}$ Department of Anatomy and Comparative Pathology and Anatomy, Veterinary Faculty, \\ University of Córdoba, Campus de Rabanales Carretera Madrid-Cádiz s/n, Córdoba, Spain
}

\begin{abstract}
Bellido, C., C. ABellán, A. MOlina, A. Blanco, R. MOYANO: Histopathological study of the Achilles tendon after exposure to bisphenol-A and its subsequent treatment with platelet growth factors. Vet. arhiv 88, 21-35, 2018.
\end{abstract}

\section{ABSTRACT}

Bisphenol-A is a well-known compound with estrogenic activity, which is produced in tons world-wide and is abundantly used as a component of food containers, so that it frequently migrates into food and appears as an environmental pollutant. This study aimed to assess the effects of Bisphenol-A at the tendon level, possible reversal after it is withdrawn from exposure, and its recovery after the application of plate-enriched plasma. For this purpose, 16 animals were randomly distributed to one of the experiment groups: control group, group treated with BPA (for 4 months), group BPA-withdrawal (treated for 2 months with BPA and two months without BPA), and platelet-rich plasma (PRP) group (treated for 2 months with BPA, when it was withdrawn and the PRP treatment began for 2 months). At the end of the treatments biopsy of the Achilles tendon was carried out. The samples were analysed by optical and electron microscopy and immunohistochemistry. Histopathology was a fundamental tool in the evaluation of the tendon after exposure to Bisphenol-A. Our results showed how, after withdrawal of BPA, there was recovery from the lesions caused, with diminution in the type III collagen fibres along with tendon vascularization processes; in the group to which PRP was applied, almost complete recovery from the lesions caused occurred, and the immunocytochemistry test was negative for the type III collagen fibres. Our results indicate that tendons were affected after BPA exposure, but that the lesions were partially reversible after BPA was withdrawn. PRP application enabled tendon lesions to recuperate and all signs of inflammation disappeared.

Key words: bisphenol-A; Achilles-tendon; collagen; histopathology; platelet-rich plasma

\footnotetext{
*Corresponding author:

Rosario Moyano Salvago, Department of Pharmacology, Toxicology and Legal and Forensic Medicine, Veterinary Faculty, University of Córdoba, Campus de Rabanales Carretera Madrid-Cádiz s/n, Córdoba 14071, Spain, E-mail: r.moyano@uco.es

\# Both authors contributed equally to the manuscript 
C. Bellido et al.: Achilles tendon evaluation after bisphenol-A and platelet rich plasma treatment

\section{Introduction}

Bisphenol-A (BPA) is a compound with an endocrine disruptor activity, which is habitually used as a component of plastics and food containers. Changes in $\mathrm{pH}$, mechanical abrasions and heat can accelerate the hydrolysis of the ester link joining the BPA molecules in polycarbonate plastic, causing it to be easily released to affect food and/or the environment (VANDENBERG et al., 2007; MILEVA et al., 2014). BPA endocrine disruptor activity has been widely studied by diverse research teams in different species (MANDICH et al., 2007; RODRÍGUEZ et al., 2010; LÓPEZ-CASAS et al., 2012; MOLINA et al., 2013; LORA et al., 2016), its interference in reproduction being the fundamental aspect most often evaluated. Apart from its deleterious action at a gonad level, it has been observed that it may exert its effects, among others, on type 2 diabetes, obesity, the hepatic function, cardiovascular alterations, oxidative stress and inflammation, and even on the musculotendinous system (VANDENBERG et al., 2013; ROCHESTER, 2013; GIMÉNEZ et al., 2016)

Over the past few years, a great deal of research has studied the recovery of tendons from trauma and tears, in treatments with growth factors. However, palliative treatments with growth factors for tendon degeneration in muscles have hardly been addressed (CUNHA et al., 2014; GIMÉNEZ et al., 2016).

When degenerative processes are produced in tendons they are usually accompanied by inflammatory phenomena, so that type I collagen fibres, specific to tendons, can coinhabit jointly with type III collagen fibres, in which the inflammation occurs. This union is a noxious one, as the type I collagen fibre is located longitudinally to the contraction axis and with undulations favouring stretching, while type III collagen fibres have an uneven distribution in all directions in the space (FERNÁNDEZ-SARMIENTO et al., 2013).

The importance of BPA as an environmental contaminant and the risk it entails, due to its low biodegradation rate and its bioaccumulation in the trophic chain, have caused the European Parliament to include it as a substance whose toxicity should be evaluated (BHANDARI et al., 2015).

Due to the risk of BPA exposure in the diet, we proposed as our study objective the evaluation of the possible effects of BPA on the Achilles-tendon using histopathology as a fundamental tool, as well as determination of its recovery capacity after the withdrawal of exposure to this compound; the response of the muscle after PRP application to animals previously exposed to BPA was also investigated.

\section{Materials and methods}

Animals. Sixteen two-month-old "Minipigs" were used from the Centralized Experimental Animal Service at the University of Córdoba, where they were stabled 
throughout the entire experiment, following the conditions specified in the guidelines relative to the housing and care of animals (RD 53/2013). All the experiment protocols were approved by the Córdoba University Committee of Bioethics. The animals were fed once a day during the study months (Nantaunic, Nantaporc $\mathrm{PI}^{\circledR}$ ) and distributed randomly to one of the four experiment groups: Control Group $(\mathrm{GC}),(\mathrm{n}=4)$; the group treated with BPA $(\mathrm{n}=4)$ orally $1 \mathrm{mg} / \mathrm{kg}$ bw/day (Sigma Aldrich ${ }^{\circledR}$, St. Luis, EE.UU.) for four months; a third group BPA-withdrawal $(n=4)$ which, after two months of treatment, was taken off BPA for two more months up to their biopsy; and the fourth group, platelet-rich plasma (PRP) $(n=4)$. The animals of this group were treated with BPA for 2 months, then it was withdrawn and they began treatment with PRP. A weekly dose of platelets was injected into their Achilles tendon for three weeks. Four months after beginning the study, samples were collected by means of biopsy of the Achilles tendon for subsequent examination. For this purpose, the animals were anaesthetized with the following anaesthetic/analgesic protocol: Buprenorfine (Buprecare ${ }^{\circledR}$ ) at a dose of $0.01 \mathrm{mg} / \mathrm{kg}, 30$ minutes before sedation via $\mathrm{IM}$, and next Zolazepam + Tiletamine $3 \mathrm{mg} / \mathrm{kg}$ (Zoletil ${ }^{\mathbb{}}$ ) was administered in combination with Medetomidine $0.05 \mathrm{mg} / \mathrm{kg}\left(\right.$ Medetor $\left.^{\circledR}\right)$ vía IM. The sample was taken 2 $\mathrm{cm}$ laterally from the midline and at a depth of $2 \mathrm{~cm}$. The penetration of the biopsy needle was achieved by making a small cutaneous incision with a scalpel.

PRP preparations. Two $\mathrm{mL}$ of blood was taken from the jugular vein using PRP kit tubes, containing $0.3 \mathrm{~mL}$ of anticoagulant and separator. After transferring the tube contents to another tube containing platelet activation-preventing substances, and centrifugation of the tube at $1700 \mathrm{rpm}$ for $12 \mathrm{~min}$, its upper component, which contained platelets and plasma, was transferred to another tube containing preservative substances. After that, the tube was centrifuged at $3500 \mathrm{rpm}$ for $7 \mathrm{~min}$. Finally, the upper portion of the tube contents was discarded and, after a 30 min delay, the remaining portion was injected into the animal.

Histological evaluation. During our study, in all the groups three essential components were assessed by means of structural and ultrastructural evaluation: cells, collagen fibres and vascularization. The study was performed by an experienced observer but who had no previous knowledge of which group was being analyzed.

Light microscopy. For the structural evaluation, the samples were routinely processed for paraffin sections by fixing in 10\% formaldehyde, dehydrating in graded series of ethanol, immersing in xylol and embedding in paraffin wax. Every tenth section (4 $\mu \mathrm{m}$ thick) of each block was stained with haematoxylin and eosin, and with Masson`s trichome, and used for the morphological study.

Electron microscopy. For the ultrastructural study, small, randomly selected samples were primarily fixed in a $2 \%$ glutaldehyde solution in $0.1 \mathrm{M}$ phosphate buffer $(\mathrm{pH} 7.4)$ overnight at $4{ }^{\circ} \mathrm{C}$, and then refixed in $1 \%$ osmium tetroxide in $0.1 \mathrm{M}$ phosphate buffer $(\mathrm{pH}$ 
C. Bellido et al.: Achilles tendon evaluation after bisphenol-A and platelet rich plasma treatment

7.4) for $30 \mathrm{~min}$. After dehydration in graded ethanol series and having been embedded in Araldite, semithin and ultra-thin sections were cut on an LKB ultramicrotome (Central Microscopy Research Facilities, University of Córdoba, Spain). Semithin sections were stained with toluidine blue, whereas ultra-thin sections were double-stained with uranyl acetate and lead citrate. Ultra-thin sections were viewed and photographed in a JEM 1400 transmission electron microscope.

Immunohistochemistry (ICH). In order to perform the IHC technique, the avidinbiotin-peroxidase $(\mathrm{ABC})$ technique protocol was carried out, in which the following steps were adhered to, using antibody 1 (anticollagen I) and antibody 2 (anticollagen III).

For this purpose the samples were deparaffinised with 3 changes in xylol of 10 minutes each, two changes in $100^{\circ}$ alcohol for 5 minutes each. Next, endogenous peroxidase was inhibited for 30 minutes ( $6 \mathrm{~mL}$ of peroxide $+194 \mathrm{~mL}$ of methanol), and then hydrated with $96^{\circ}, 70^{\circ}$ alcohol and bi-distilled water, for 5 minutes each. The $\mathrm{pH}$ in PBS 7.2 was adjusted for 10 minutes. Subsequently, an enzymatic pre-treatment with pronase was performed for 10 minutes by stirring $(0.2 \mathrm{~g}$ of pronase $+200 \mathrm{~mL}$ of PBS). The enzymatic digestion was halted by means of 3 PBS baths of 10 minutes each. The background staining was suppressed by incubation with normal $10 \%$ goat serum. Finally, the $1^{\text {st }}$ antibody was incubated for $8 \mathrm{~h}$. at $4{ }^{\circ} \mathrm{C}$. The next day the platelets were left for 1 hour at room temperature, followed by three PBS baths of 10 minutes each. The $2^{\text {nd }}$ antibody was incubated for 30 minutes at room temperature and then submitted to PBS baths of 10 minutes each. The ABC complex was left for 1 hour at room temperature and in darkness, followed by 3 baths of TRIS pH 7.6 for 5 minutes each. It was developed in a chromogenic solution ( $0.07 \mathrm{~g}$ of diamine $+200 \mathrm{~mL}$ of TRIS $+200 \mu \mathrm{L}$ of peroxide) for 1 minute at room temperature (by agitation and in darkness), and then rinsed for 10 minutes in tap water. Next, it was counter-stained with haematoxylin for 15 seconds and rinsed again with tap water. Finally, it was dehydrated, clarified and mounted.

\section{Results}

The control group (Fig. 1). Cells or tendocytes are responsible for directing the metabolism of tendon tissue, and basically that of the collagen fibres. These cells appeared as rows parallel to each other, arranged in a longitudinal direction along the tendon. Under the optical microscope (O.M.), highly elongated cells were observed with a nucleus located in the centre of the cytoplasm. The cell edge was somewhat unclear, and the cytoplasm highly elongated, scant, and with a clear basophilia. In the studies under electronic microscope (E.M.) we were able to verify the close relationship between the tendocytes and the collagen fibres. The fibres pressed onto the cells, modifying their morphology in such a way that the cytoplasm exhibited some cytoplasmic extensions, like wings, so that tendocytes are also known as wing cells. Both the nucleus and the 
cytoplasm displayed the morphology of the fibrocytic cells in a resting phase, so that the cytoplasmic organoids were scarcely developed, with evidence of ribosomes, which were those generating the basophilia.

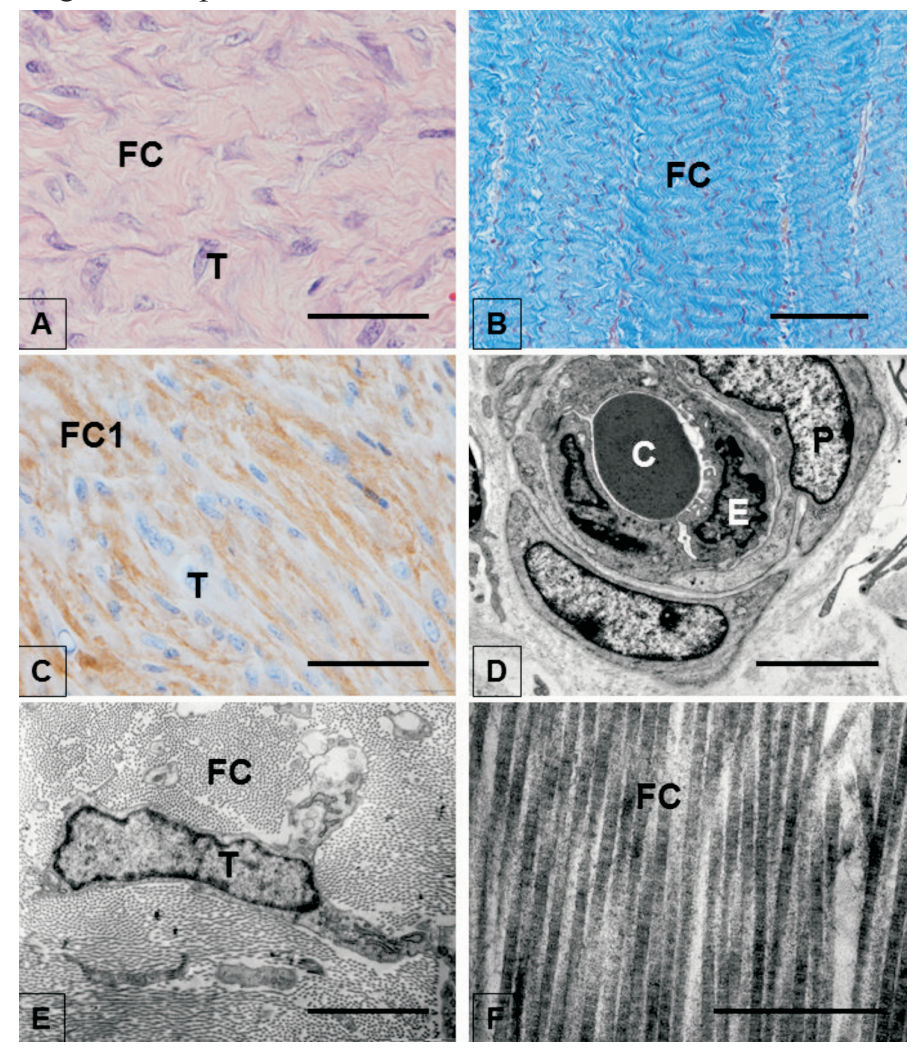

Fig.1. Control group. Light microscope. Scale bars $=10 \mu \mathrm{m}(\mathrm{A}),(\mathrm{B}),(\mathrm{C})$ ultrastructural observations. Scale bars $=10 \mu \mathrm{m}(\mathrm{D}),(\mathrm{E}),(\mathrm{F})$.

Inset of normal tendon with collagen fibre fasciculi (FC) and tendocytes (T). H\&E; Inset of normal tendon, with thick undulated fasciculi (FC), Masson's trichrome stain; Inset of normal tendon. Note the presence of type I (FC1) collagen and tendocytes (T). Immunocytochemistry with anticollagen 1 serum; Inset of mature capillary $(\mathrm{C})$ with a developed endothelium (E) and pericytes $(\mathrm{P})$; Normal tendon with tendocytes $(\mathrm{T})$ with

cytoplasmic prolongations and collagen fibres (FC), Normal tendon; Inset of collagen fibres (FC) with organized striae.

The collagen fibre observed was type I, therefore the reaction to type III was negative or scar-like. This component was arranged in thick fasciculi, parallel to each other, 


\section{Bellido et al.: Achilles tendon evaluation after bisphenol-A and platelet rich plasma treatment}

and arranged following its longitudinal axis in order to support the tensile forces that could be produced in it. However, in order to bear a minimum of longitudinal traction, trichrome staining enabled us to prove that the collagen fasciculi showed a certain level of undulations, which could be involved in producing a small stretch and its subsequent recovery.

Under the E-M, the fibre fasciculi were homogeneous, and the intimate composition of the collagen fibres was above all highly uniform, with the classic clear and dark tranversal striae, presenting a very even and uniform composition.

As the Achilles tendon is a densely modelled connective tissue, it is characterized by scant vascularization, which comes from a fine mesotendon. Its arteries and veins displayed a minimal expression, and the most noticeable component were its capillaries. The latter showed a composition of mature vessels, in which the light was enveloped by endothelial cells, and, more important, they showed well developed pericytes or Rouget cells, in the presence of cytoplasmic actin.

The group treated with BPA (Fig. 2). In order to learn whether they were altered after BPA exposure, we had to take into account the tendocytes, the collagen fibres, and especially their vascularization. In inflammatory processes in the tendon, two types of cells presented: on the one hand tendocytes and on the other, participating in the inflammatory and scarring processes, fibre-producing cells known as fibroblasts were observed.

The tendocytes were arranged in rows parallel to each other, and neovascularization occurred between them, separating them. These cells were elongated, basophilic with elongated nuclei and unclear cytoplasmic edges. Under the E.M., the tendocytes displayed the morphology of fibroblastic cells, with an elongated nucleus with a dense chromatin, and the cytoplasm had few cytoplasmic organoids, which corresponded to mature fibroblastic cells. A few ribosomes, a rough reticulum, and a Golgi complex appeared. In the inflammatory cells, the fibroblastic cells stood out, and were found within the tendon and near the vascular beds. They had an irregular morphology, defined by a broad, rough reticulum with irregular cisternae, arranged over the whole cell surface, so that the neoformed fibres could be released in all directions. Some inflammatory cells were found, such as macrophages, lymphocytes and red blood cells.

One notable aspect was the increase in the vascularization with neovessels in the tendon, which ranged from meta-arterioles and venules, to, especially, abundant capillaries, which were usually hyperaemic.

Alterations appeared in the collagen fibres: first, using the immunocytochemistry technique, it was notable that these fibres were type III (scar collagen); and second, they partly lost their distribution in the fasciculi parallel to each other, following irregular paths, and partly losing their tendocyte relationship. 

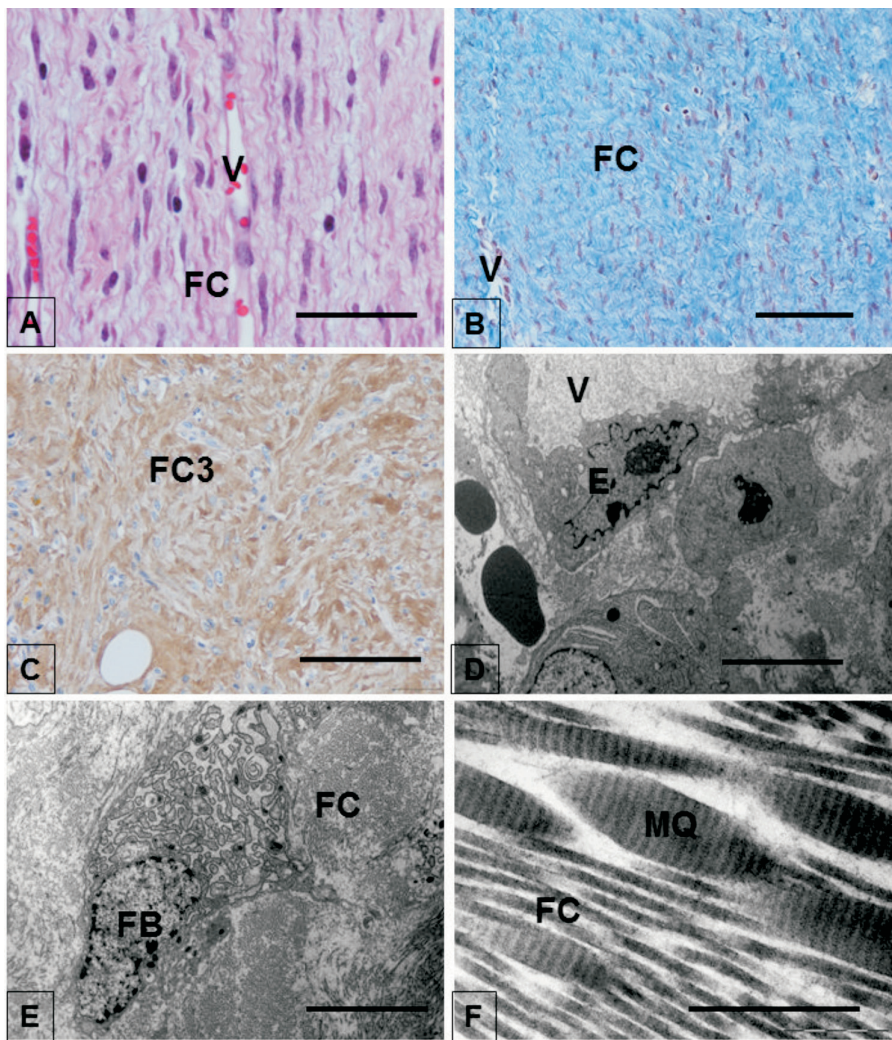

Fig. 2. Histological changes in BPA group. Light microscope. Scale bars $=10 \mu \mathrm{m}(\mathrm{A}),(\mathrm{B}),(\mathrm{C})$ ultrastructural observations. Scale bars $=10 \mu \mathrm{m}(\mathrm{D}),(\mathrm{E}),(\mathrm{F})$;

Inset of tendon with disorganized collagen fibres (FC), and abundant vessels (V). H\&E-stained; Presence of fibre fasciculi without undulations (FC) and abundant vessels (V). Masson's trichrome stain; Inset of tendon with abundant type III collagen (FC3). Immunocytochemistry of anticollagen collagen 3; Neoformed capillaries with dilated lights (V) and swollen endothelial cells (E); Disorganized collagen fibre fasciculi (FC) and fibroblasts (FB); Inset of collagen fibres (FC), in which a thickening by way of microkeloids is noted

(MK)

Diffusely, or in small deposits, the collagen fibres showed thickenings in their constitution and under EM, maintaining their striae, which corresponded to microkeloids.

The BPA-withdrawal group (Fig. 3). In relation to the cells, on the one hand tendocytes were identified and on the other fibroblasts. The tendocytes retained the morphology of mature fibroblastic cells, elongated, with elongated, dense nuclei, a scant basophilic cytoplasm and sparse cytoplasmic organoids. A fibroblastic cell was maintained, which 
corresponded to fibroblasts, with an irregular morphology, a prominent, highly-developed rough reticulum, and dilated lights with a homogeneous, clear content. The elimination of the fibres was found over the whole cell surface.
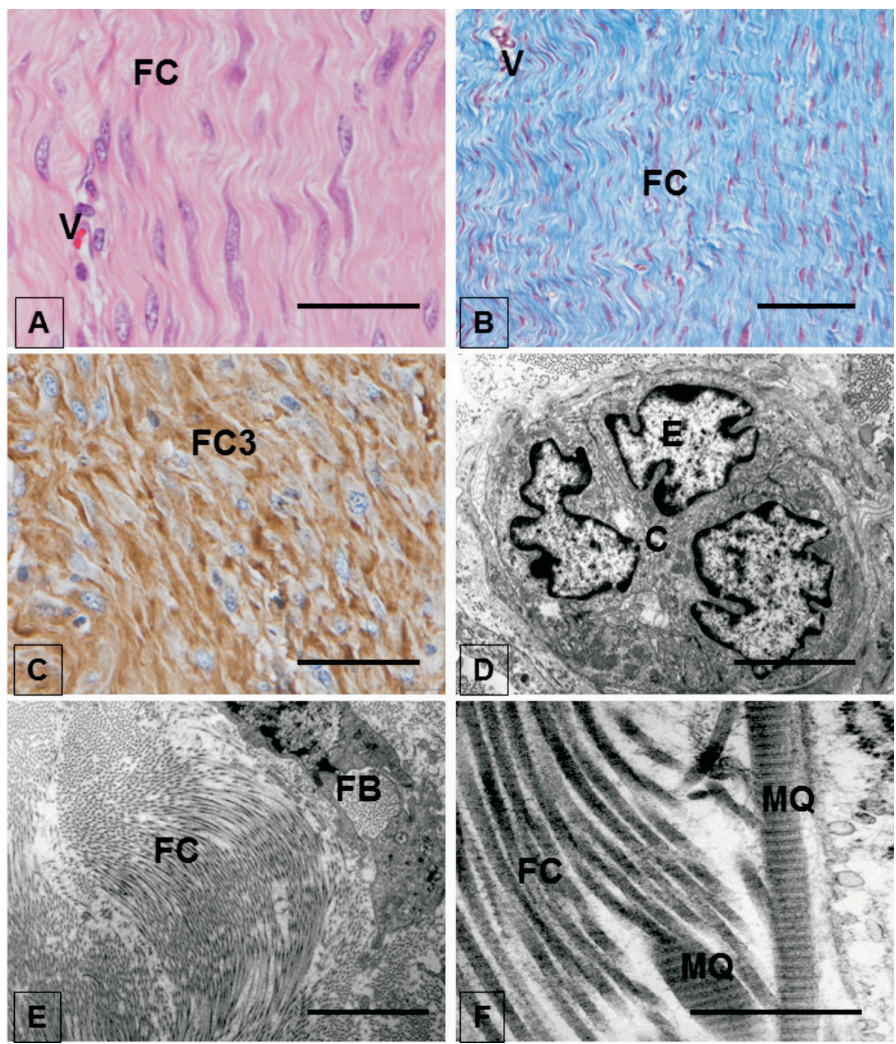

Fig. 3. Histological changes in BPA-withdrawal group. Light microscope. Scale bars $=10 \mu \mathrm{m}(\mathrm{A})$, (B), (C) ultrastructural observations. Scale bars $=10 \mu \mathrm{m}(\mathrm{D}),(\mathrm{E}),(\mathrm{F})$.

Presence of thickened collagen fibre fasciculi (FC) and some vessels (V). H\&E-stained; Inset of undulated collagen fasciculi (FC), and vessels (V). Masson's trichrome stain; Presence of type 3 collagen fibre fasciculi (FC3). Immunocytochemistry ant collagen 3 serum; Young capillaries (V), with swollen endothelial cells (E); Presence of abundant collagen fasciculi (FC) with disorganized fibres and fibroblasts (FB); Inset of collagen fibres (FC), with thickening by way of microkeloids (MK).

Clear vascularization appeared, especially capillary, although less than in the previous group, and in fibrous bridles, vessels of a higher calibre.

The collagen fibres were mostly of type III, scar collagen, which co-existed with the type I collagen fibres, and, under OM, a highly irregular distribution was noted, maintaining a scant relationship with the tendocytes. 
Under EM, most of the fibres were irregular and even appeared hypertrophic, with clearly marked striae.

The PRP-group (Fig. 4). Considering that cells are an essential component on which growth factors act and that their activation is responsible for tendon recovery, it should be noted that the cells studied may be categorized into two types. These are: first, tendocytes, and second, highly activated tendocytes, in the mode of fibroblastic cells, which are termed "tendocytoblasts" as they are responsible for the formation of collagen fibres.

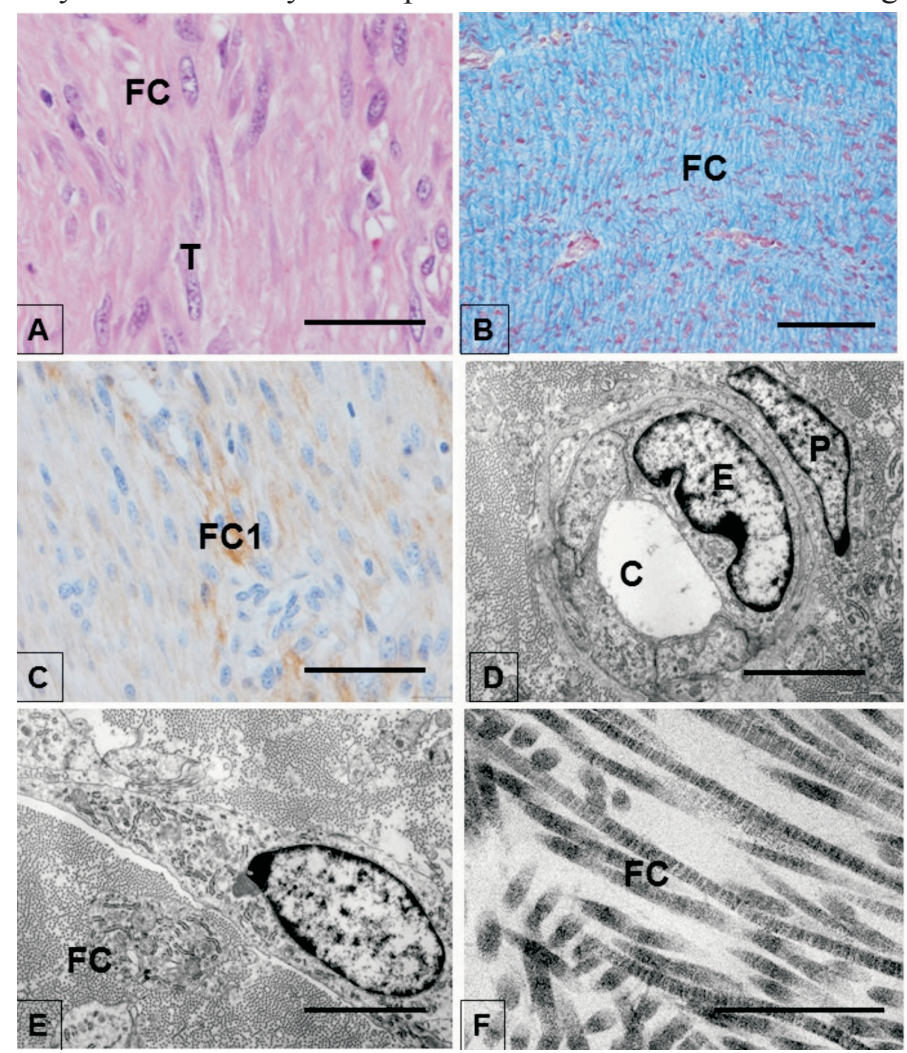

Fig. 4. Histological changes in PRP group. Light microscope. Scale bars $=10 \mu \mathrm{m}(\mathrm{A}),(\mathrm{B}),(\mathrm{C})$ ultrastructural observations. Scale bars $=10 \mu \mathrm{m}(\mathrm{D}),(\mathrm{E}),(\mathrm{F})$.

Presence of collagen fibre fasciculi (FC) and tendocytes (T). H\&E- stained; Presence of thick collagen fibre fasciculi (FC), undulated and parallel to each other. Masson`s trichrome stain; Inset of type 1 collagen fibre (FC1), recently formed. Immunocytochemistry anti collagen 1; Capillaries (C), organized with endothelium (E) and pericytes (P); Inset of fibroblasts with a highly active reticulum and organized collagen fibres (FC); Inset of mature fibres (FC), with highly defined striae. 


\section{Bellido et al.: Achilles tendon evaluation after bisphenol-A and platelet rich plasma treatment}

The inflammatory and degenerative processes practically disappeared, and in their place the tendocytes showed themselves to be mature cells, related to the fibres and arranged in rows parallel to each other, with an elongated morphology and dense nuclei, and evident cytoplasmic organoids. However, the cells that were of most interest were the tendocytoblasts, which occupied the place of the fibroblasts and were not only responsible for forming the fibres, but also for their subsequent orientation within the tendon. The fibres forming these cells belonged to type 1 collagen and not type III, which corresponds to the scarring processes. The "tendocytoblasts" were seen to be large, highly basophilic, elongated cells. Under the EM, a large amount of organoids were observed, as well as a Golgi complex and, above all, a rough reticulum, whose lights were not dilated and which showed a patently obvious lining of ribosomes.

In this group, the vascular bed had diminished, leaving practically only capillaries, correctly formed and mature with a lining of pericytes and little associated fibrous tissue.

The collagen fibres reacted negatively to collagen type III, and when forming themselves, they showed the longitudinal trajectory characteristic of the tendocytoblasts. Together with their longitudinal orientation, a classic smooth undulation was noted in these components. Finally, under the EM, the fibres were homogeneous with uniform striae, without exhibiting at any time thickenings or atypical structures.

\section{Discussion}

Endocrine-disrupting chemicals (EDCs) have received a great deal of scientific and public attention worldwide due to their potentially adverse effects on environmentally exposed organisms. The widespread distribution and environmental persistence of the xenoestrogen BPA is likely to result in strong potential for human and animal exposure, which is relevant for public health because humans are exposed to this compound on a daily basis (GRASELLI et al., 2010).

Previous studies by our research team have enabled us to confirm that exposure to compounds with a disruptor activity cause degenerative processes at a gonad level (BLANCO et al., 2007; BLANCO et al., 2009; PATRIGNANI et al., 2014). We have also seen how BPA triggers important effects on ovaries and testicles, which could interfere with fertility (MOLINA et al., 2013; LORA et al., 2016), in addition to modifying other systems, such as the musculoskeletal system (GIMÉNEZ et al., 2016).

The estrogenizing action of BPA produces an increase in the endogenous production of 17- $\beta$-estradiol and of other hormones, which are naturally synthesized in the organism, but when exposed to the disruptor, their production is increased (YANG et al., 2016). This fact could indicate that the effects generated in the musculoskeletal tissue could be produced as secondary to the action of BPA, because these endogenous hormones could act in an anabolizing manner (HUANG and SILLENCE, 2000). In our study, we observed 


\section{Bellido et al.: Achilles tendon evaluation after bisphenol-A and platelet rich plasma treatment}

that, in the group exposed permanently to BPA, degenerative processes occurred, which affected both the cells and the collagen fibre fasciculi. These alterations were aggravated by inflammatory interference, which seriously modified the degeneration, and which were the cause not only of a loss of functionality but also of possible tendon ruptures. That type of lesion is similar to those produced as a result of the metabolic diseases previously described by ABATE et al. (2013). These inflammatory processes could be considered as vicariant to counteract degeneration, but these defensive systems could be negative since one of the phenomena entailed was the appearance of blood vessels in the tendon territory, which transformed the mesotendons into thick connective cords with neovessels. This situation results in the generation of adherence of the tendon to the sheaths, so that mobility could be lost. These tendon fixation points were intensified when collagen III was produced indiscriminately by the scarring fibroblasts, a problem which could affect athletes. If there is a change in the structural organization of collagen tissue, its biomechanical properties could be changed (JEFFREY and JEFFREY, 1991).

From the results obtained we verified that the effects produced by the action of the bisphenol were reversible, so that when the BPA exposure ceased, the degenerative action did too. However, due to the type of fibrous connective tissue formed in the tendons, their total recovery was incomplete, especially because the adherence points of the tendon to the sheath were maintained. This produced an anchoring area, which reduced their sliding movement, and also because the type III formed by the scarring lacked the capacity to organize itself into thick longitudinal fasciculi, and it was usually arranged as fibrous areas within the tendon, thus losing its traction ability. Normally, type III collagen fibres show a striated morphology, but when they are formed inside fibrous tissues they are abnormally synthesized and some atypical thickenings, known as microkeloids, are produced, and they turn into rupture-sensitive areas (ABATE et al., 2013; ROCHESTER, 2013). At present, there are no references regarding direct BPA action in the tendon, and very few related to its action in the muscle (MORTAVAZI et al., 2013; WANG et al., 2013; GIMÉNEZ et al., 2016). However, in this regard, the modifications observed by GIMÉNEZ et al. (2016) could be compatible with those caused by exogenous treatments with hormonal compounds, coinciding at this point with previous studies, in which an increase in abnormal collagen fibre was reported after anabolic steroid administration (JEFFREY and JEFFREY, 1991). In our study, we observed that, in both the BPA group and in BPA-withdrawal, the collagen III was kept immersed in collagen I, a situation which caused the collagen III to increase the polymerization of the tropocollagen and, instead of forming homogeneous collagen with striae, microkeloids were detected, which could turn into rupture areas.

In the PRP group, the inflammatory processes were halted with the application of platelet growth factors to the tendon, and a drastic decrease in vessels was noted. Thus, 


\section{Bellido et al.: Achilles tendon evaluation after bisphenol-A and platelet rich plasma treatment}

the arrival of inflammatory components was stopped, highlighting the loss of tendon adherences, and the mesotendon became finer and more flexible. In normal scarring processes, fibroblasts produce fibrosis, but in studies on tendon rupture treatments with platelet growth factors, the tendocytes themselves are transformed into "tendocytoblasts", and, instead of synthesizing type III collagen fibres, they form collagen type I, which are arranged in fasciculi, laid out longitudinally (MOLLOY et al., 2003; HSU and CHANG, 2004; GAWEDA et al., 2010).

This study enabled us to monitor processes of a diverse nature, which are compatible with others described in tendon ruptures treated with platelets. The scarring fibroblasts decreased and even disappeared, and there was also cellular activation of the tendocyte, which increased in size and developed protein-forming organoids, which were basically a rough reticulum and a Golgi complex. In addition, the organoids presented a longitudinal orientation, parallel to the collagen fasciculi. The reduction in the scarring fibroblasts was responsible for the notable diminution of collagen III, and the activation of the tendocytes favoured the formation of collagen I. Due to the longitudinal distribution of its tendon cells, this collagen I was arranged longitudinally along the tendon axis, facilitating the formation of the fibrous fasciculi, which showed undulations in the longitudinal direction at the tendon axis. This demonstrated the regenerative capacity of the PRP in lesions caused by BPA exposure, which would guarantee the functionality of the tendon.

\section{Conclusions}

Our results indicate that tendons are seen to be affected after exposure to BPA and exhibit inflammatory processes, neovascularization and type III collagen fibres. It was observed that these lesions may be reversible since, when withdrawing BPA exposure, recovery phenomena appeared, with a decrease in inflammatory episodes, although the remains of the fibrosis and adherences persisted. However, after the application of PRP, the tendon recovered, forming type I fibres and "tendocytoblasts", with the disappearance of any sign of inflammation. Therefore, we are able to affirm the suitability of the use of growth factors in the treatment of tendon lesions caused by exogenous exposure to estrogenic substances.

\section{Acknowledgements}

The authors wish to thank the Spanish Junta de Andalucía (P09-AGR-514) for their financial support for this study.

The authors wish to thank the Institud für Pathologie Stiftung Tieräzliche Hochschule Hannover (Germany), especially Dr Wolfgang Baumgärtner and the technician of the electron microscopy for their encouragement during the ultrastructural images evaluation.
} 
C. Bellido et al.: Achilles tendon evaluation after bisphenol-A and platelet rich plasma treatment

\section{References}

ABATE, M., C. SHIAVONE, V. SALINI, I. ANDIA (2013): Occurence of tendon pathologies in metabolic disorders. Rev. Rheumatol. 52, 599-608.

BLANCO, A., R. MOYANO, A. MOLINA, C. BLANCO, R. FLORES-ACUÑA, R. GARCÍAFLORES, M. ESPADA, J. G. MONTERDE (2009): Quantitative study of Leydig cell populations in mice exposed to low doses of cadmium. Bull. Environ. Contam. Toxicol. 82, 756-760.

BLANCO, A., R. MOYANO, J. VIVO, R. FLORES-ACUÑA, A. MOLINA, C. BLANCO, E. AGÜERA, J. G. MONTERDE (2007): Quantitative changes in the testicular structure in mice exposed to low doses of cadmium. Environ. Toxicol. Pharmacol. 23, 96-101.

BHANDARI, R., S. DEEM, D. HOLIDAY, C. JANDEGIAN, C. KASSOTIS, S. NAGEL, D. TILLITT, F. VOM SALL, C. ROSENDELD (2015). Effects of the environmental estrogenic contaminants bisphenol A and $17 \alpha$-ethinyl estradiol on sexual development and adult behaviors in aquatic wildlife species. Gen Comp. Endocrinol. 214, 195-219.

CUNHA, R. C., J. C. FRANCISCO, M. A. CARDOSO, M. A. MATOS, L. F. MATOS, D. LINO, R. B. SIMEONI, G. PEREIRA, A. C. IROIDA, P. R. SIMEONI, L. C. GUANITA-SOUZA, K. A. CARVALHO (2014): Effect of platelet rich plasma therapy associated with exercise training in musculoskeletal healing in rats. Transplant. Proc. 46, 1879-1881.

FERNÁNDEZ-SARMIENTO, J. A., J. M. DOMINGUEZ, M. M. GRANADOS, J. MORGAZ, R. NAVARRETE, J. M. CARRILLO, R. J. GÓMEZ-VILLAMANDOS, P. MUÑOZ-RASCÓN, J. MARÍN DE LAS MULAS, Y. MILLÁN, M. GARCÍA-BALLETBÓ, R. CUGAT (2013): Histological study of the influence of plasma rich in growth factors (PRGF) on the healing of divided achilles tendons in sheep. J. Bone Joint Surg. Am. 95, 246-255.

GAWEDA, K., M. TARCZYNSKA, W. KRZYZANOWSKI (2010): Treatment of Achilles tendinopathy with platelet-rich plasma. Int. J. Sports Med. 31, 577-583.

GIMÉNEZ, M., A. MOLINA, A. BLANCO, M. AYALA, R. MOYANO (2016): Structural and ultrastructural evaluation of fibre muscles after exposure to Bisphenol-A, and a study of their possible recovery after treatment with platelet-rich plasma. Vet. arhiv 86, 49-64.

GRASELLI, F., L. BARATTA, L. BAIONI, S. BUSSOLATI, R. RAMONI, S. GROLLI, G. BASINI (2010): Bisphenol A disrupts granulosa cell function. Domest. Anim. Endocrinol. 39, 34-39.

HSU, C., J. CHANG (2004): Clinical implications of growth factors in flexor tendon wound healing. J. Hand. Surg. Am. 29, 551-563.

HUANG, H., N. SILLENCE (2000): Differential effect of dexamethasone and clenbuterol on rat growth and on beta 2-adrenoceptors in lung and skeletal muscle. J. Anim. Sci. 78, 604-608.

JEFFERY, T. L., A. R. JEFFREY (1991): Anabolic steroid-induced tendon pathology: a review of the literature. Medicine \& Science in Sports \& Exercised 23, 1-3.

LÓPEZ-CASAS, P., S. C. MIZRAK, L. A. LÓPEZ-FERNÁNDEZ, M. PAZ, D. G. DE ROOIJ, J. DEL MAZO (2012): The effects of different endocrine disruptors defining compound-specific alterations of gene expression profiles in the developing testis. Reprod. Toxicol. 33, 106-115.

Vet. arhiv 88 (1), 21-35, 2018 
C. Bellido et al.: Achilles tendon evaluation after bisphenol-A and platelet rich plasma treatment

LORA, A., A. MOLINA, C. BELLIDO, A. BLANCO, J. G. MONTERDE, R. MOYANO (2016): Effects of bisphenol-A on the testicular parenchyma of zebrafish using histomorphologic methods. Vet. Med. 61, 577-589.

MANDICH, A., S. BOTTERO, E. BENFENATI, A. CEVASCO, C. ERRATICO, S. MAGGIONI, A. MASSARI, F. PEDEMONTE, L. VIGANO (2007): In vivo exposure of carps to graded concentrations of bisphenol A. Gen. Comp. Endocrinol. 153, 15-24.

MILEVA, G., S. L. BAKER, A. KONKLE, C. BIELAJEW (2014): Bisphenol-A: epigenetic reprogramming and effects on reproduction and behavior. Int. J. Environ. Res. Public Health $11,7537-7561$.

MOLINA, A., A. LORA, A. BLANCO, J. MONTERDE, N. AYALA, R. MOYANO (2013): Endocrine-active compound evaluation: Qualitative and quantitative histomorphological assessment of zebrafish gonads after bisphenol-A exposure. Ecotox. Environ. Safe. 88, 155162.

MOLLOY, T., Y. WANG, G. MURRELL (2003): The roles of growth factors in tendon and ligament healing. Sports Med. 33, 381-394.

MORTAVAZI, S, A. R. BAKHTIARI, A. E. SARI, N. BAHRAMIFAR, F. RAHBARIZADEH (2013): Occurrence of endocrine disruption chemicals (Bisphenol A, 4-Nonyphenol, and Octylphenol) in muscle and liver of, Cyprinus carpio, from Anzali Wetland, Iran. Bull. Environ. Contam. Toxicol. 90, 578-584.

PATRIGNANI, N., A. MOLINA, A. BLANCO, M. AYALA, R. MOYANO (2014): Structural and ultrastructural evaluations of zebrafish ovaries after exposure to 2,3,7,8-tetrachlorodibenzo- $p$ dioxin (TCDD). Acta Adriatica 54, 3-12.

ROCHESTER, J. R. (2013): Bisphenol A and human heatlh: a review of the literature. Reprod. Toxicol. 42, 132-155.

RODRÍGUEZ, H. A., N. SANTAMBROSIO, C. G. SANTAMARÍA, M. MUÑOZ-DE-TORO, E. H. LUQUE (2010): Neonatal exposure to bisphenol A reduces the pool of primordial follicles in the rat ovary. Reprod. Toxicol. 30, 550-517.

VANDENBERG, L. N., S. EHRLICH, S. M. BELCHER, N. BEN-JONATHAN, D. C. DOLINOY, P. A. HUGO, R. R. NEWBOLD, B. S. RUBIN, K. S. SAILI, A. SOTO, H. WANG, F. S. VOM SAAL (2013): Low dose effects of bisphenol A: An integrated review of in vitro, laboratory, animal, and epidemiology studies. Endocrine disruptors 1, e26490, (online journal).

DOI: $10.4161 /$ endo. 26490

VANDENBERG, L. N., R. HAUSER, M. MARCUS, N. OLEA, W. V. WELSHONS (2007): Human exposure to bisphenol A (BPA). Reprod. Toxicol. 24, 139-177.

WANG, X., Q. DON, Y. CHEN, H. JIANG, Q. XIAO, Y. WANG (2013): Bisphenol A affects axonal growth, musculature and motor behavior in developing zebrafish. Aquat. Toxicol. 142$143,104-113$. 
C. Bellido et al.: Achilles tendon evaluation after bisphenol-A and platelet rich plasma treatment

YANG, X., Y. LIU, J. LI, M. CHEN, D. PENG, Y. LIANG, M. SONG, J. ZHANG, G. JIANG (2016): Exposure to bisphenol AF disrupts sex hormone levels and vitellogenin expression in zebrafish. Environ. Toxicol. 31, 285-294.

Received: 20 September 2016

Accepted: 13 June 2017

\section{BEllido, C., C. ABEllán, A. MOLina, A. Blanco, R. MOYANO: Histopatološko istraživanje Ahilove tetive nakon izlaganja bisfenolu A i naknadnog liječenja trombocitnim faktorima rasta. Vet. arhiv 88, 21-35, 2018. \\ SAŽETAK}

Bisfenol A (BPA) poznat je spoj s estrogenskom aktivnošću koji se u tonama proizvodi širom svijeta. Obilno se koristi kao sastavni dio ambalaže za hranu, u koju često migrira i pojavljuje se kao onečišćivač u okolišu. Namjera ovog istraživanja bila je procijeniti učinke bisfenola A na tetive, zatim procijeniti promjene koje se na tetivama mogu uočiti nakon prestanka izloženosti bisfenolu A te analizirati oporavak tetiva nakon primjene plazme obogaćene trombocitima. U tu je svrhu metodom slučajnog izbora 16 životinja podijeljeno u jednu od eksperimentalnih skupina: kontrolnu skupinu, skupinu izloženu BPA (tijekom 4 mjeseca), skupinu kod koje je nakon izloženosti povučen BPA ( 2 mjeseca izložena BPA i dva mjeseca bez BPA) i skupinu koja je dobila plazmu obogaćenu trombocitima - PRP (2 mjeseca izložena BPA zatim, nakon što je BPA povučen, primijenjeno je liječenje PRP-om tijekom 2 mjeseca). Na kraju liječenja učinjena je biopsija Ahilove tetive. Uzorci su analizirani optičkom i elektronskom mikroskopijom te imunohistokemijskim metodama. Uporaba histopatologije bila je temeljni alat za procjenu tetive nakon izlaganja bisfenolu A. Rezultati su pokazali da je nakon uklanjanja BPA došlo do oporavka od uzrokovanih lezija, s redukcijom kolagenih vlakana tipa III i procesima vaskularizacije tetive, a u skupini u kojoj je primijenjen PRP oporavak od nastalih lezija bio je gotovo potpun i imunocitokemijski test na kolagena vlakna tipa III bio je negativan. Pokazalo se da su tetive, nakon izlaganja BPA bile oštećene, ali da su lezije nakon uklanjanja BPA bile djelomično reverzibilne. Primjena PRP-a dovela je do oporavka od lezija na tetivama i nestanka bilo kakvih znakova upale.

Ključne riječi: bisfenol A; Ahilova tetiva; kolagen; histopatologija; plazma bogata trombocitima 
